\title{
Profit Maximization of DELL Inc. through Build-to-Order Supply Chain for Laptop Manufacturing
}

\author{
Mahmud Parvez, Neamat Ullah, Mohammad Ali Sabuj, Sybon Islam \\ Department of Industrial Engineering and Management (IEM), Khulna University of Engineering \& Technology (KUET), \\ Khulna, Bangladesh \\ Email: parvezmahmud@yahoo.com,neamat1385@gmail.com, sabuj_sam@yahoo.com,sybon00@gmail.com
}

How to cite this paper: Parvez, M., Ullah, N., Sabuj, M.A. and Islam, S. (2018) Profit Maximization of DELL Inc. through Build-to-Order Supply Chain for Laptop Manufacturing. American Journal of Industrial and Business Management, 8, 1657-1671.

https://doi.org/10.4236/ajibm.2018.86110

Received: April 1, 2018

Accepted: June 24, 2018

Published: June 27, 2018

Copyright $\odot 2018$ by authors and Scientific Research Publishing Inc. This work is licensed under the Creative Commons Attribution International License (CC BY 4.0).

http://creativecommons.org/licenses/by/4.0/

\begin{abstract}
The Build-to-order supply chain management (BOSC) strategy has recently attracted the attention of both researchers and practitioners, given its successful implementation in many companies including Dell computer, Compaq and BMW. The era is becoming modern day by day and the variation in demand of men is changing with one accord. At beginning stage, men would use personal computer (PC) but they could not use PC according their preference. After some time of that period, DELL Inc. first launched PC according to customer need and they gained a great market share. After that, a new technology had come that is laptop. As a result, laptop market share crossed the PC market share. Different company is developing standardized laptop but no one is actually paying attention to the customer preference. This work represents a model of BTO production of laptops and the profit estimation which represents how BOSC strategy on DELL laptop would increase the profit. In this research paper, we have developed an optimum supply chain network and build-to-order (BTO) management for laptop manufacturing of DELL Inc. and also showed that how can be more profitable by applying this strategy.
\end{abstract}

\section{Keywords}

Build-to-Order Supply Chain Management, Supply Chain Network Distribution, Implementation Strategy, Performance Measurement

\section{Introduction}

A typical supply chain network consists of various stages i.e. supplier, manufacturer, distributor, retailer, customer [1] [2]. Sultana et al. (2016), Munna et al. (2015) and Mondal et al. (2017) stated that each of the stages creates extra charge 
to the final products [3] [4]. Mondal et al. also stated that the more stages present in supply chain, the more complex network creates [4]. As the complexity increases, more highly skilled personnel will be required, which eventually increases the cost of supply chain. If we can reduce some stages of the supply chain network, it can be easily said that it will reduce the supply chain cost. Sultana et al. stated that nowadays in the business world, companies are trying hard to gain competitive advantage over others by offering their customer satisfactory quality, price, responsiveness, flexibility, and dependability [3]. Towards this end, firms have developed a build-to-order supply chain (BOSC) to be flexible and responsive [5]. According to Sun et al. (2006), BOSC has become a popular operations paradigm after the success of its implementation in Dell Computers, BMW, and Compaq [6]. Dell operated on the direct sales model, taking orders over the phone and building PCs to the customer's specifications. Dell entered the retail PC channel for several years in the early 1990s, but a downturn in business in 1993 led it to return to its roots as a direct vendor (although the company does work with resellers in some markets). Dell grew rapidly and in the mid of 1990s, its sales reached an inflection point, soaring from $\$ 3.5$ billion in 1994 to $\$ 25$ billion in 1999. By 1999, Dell had become the number one PC seller in the United States, and was number two worldwide. More importantly, profits were soaring, thanks to the cost structure of the direct, build-to-order model. Dell's most recent $26 \%$ growth rate continues to outpace the industry as a whole, and it has not been able to match its earlier growth rates of $50 \%$ a year. And it was hit hard by the slowdown in PC sales in late 2000. The result has been a sharp fall in Dell's stock price and a reminder that Dell is vulnerable to the brutal price competition and cyclical demand of the PC industry [7].

\section{Literature Review}

Several review articles were found on Build-To-Order supply chain management, but none on BOSC provided an analytical framework for a critical review of the literature on Total Supply Chain Management (TSCM) which can be best suited for newly proposed BOSC strategy in laptop production of DELL Inc. For the research purpose the studies available on BOSC are reviewed and they are listed in Table 1 (Summary of references under the detailed classification scheme of the literature on BOSC).

\section{Build to Order Supply Chain Management}

The manufacturing continuum can be classified as make-to-stock (MTS), assemble-to-stock (ATS), make-to-order (MTO), and engineering-to-order (ETO). BTO and MTO are similar. MTO indicates the manufacturing of component and parts along with assembly, but BTO includes mostly assembly operation, where the component and parts outsourced [5]. For that reason, BTO are more responsive than MTO. And that is why different companies are changing their strategy and moving towards the BTO and establishing BOSC for increasing responsiveness. 
Table 1. Classification of the literature available on BOSC.

\begin{tabular}{|c|c|}
\hline $\begin{array}{c}\text { Classification } \\
\text { criteria }\end{array}$ & Classified by \\
\hline $\begin{array}{l}\text { Supply chain and } \\
\text { BTO } \\
\text { environment }\end{array}$ & $\begin{array}{l}\text { Hausman (2004) [8], Noorul Haq \& Kannan (2006) [9], Gosling \& Naim, (2009) } \\
\text { [10], Christensen et al. (2005) [11], Gunasekaran \& Ngai (2005) [5], Ho \& Lin } \\
\text { (2004) [12], Prasad et al. (2005) [13], Holweg \& Pil (2001) [14] }\end{array}$ \\
\hline $\begin{array}{l}\text { Development and } \\
\text { implementation } \\
\text { of BOSC }\end{array}$ & $\begin{array}{l}\text { Cravens et al. (2000) [15],Vrijhoef and Koskela (2000) [16], Forza and Salvador } \\
\text { (2002) [17], Muffato and Payaro (2002) [18], Power and Sohal (2002) [19], } \\
\text { Svensson and Barford (2002) [20], Thonemann and Bradley (2002) [21], Van } \\
\text { Tulder and Mol (2002) [22], Chopra (2003) [23], Davila et al. (2003) [24], Erhun } \\
\text { and Tayur (2003) [25] }\end{array}$ \\
\hline $\begin{array}{l}\text { Operations of } \\
\text { BOSC }\end{array}$ & $\begin{array}{l}\text { Banker and Khosla (1983) [26], Glasserman and Wang (1998) [27], Krause et al. } \\
\text { (1998) [28], Chen et al. (2000) [29], Chen et al. (2003) [30], Griffiths and } \\
\text { Margetts (2000) [31], Kolisch (2000) [32], Song and Yao (2002) [33], Geunes } \\
\text { (2003) [34], Wagner et al. (2003) [35], Biswas and Narahari (2004) [36] }\end{array}$ \\
\hline $\begin{array}{l}\text { BOSC and } \\
\text { information } \\
\text { technology }\end{array}$ & $\begin{array}{l}\text { Kraemer and Dedrick (2002) [37], Morris and Morris (2002) [38], Muffato and } \\
\text { Payaro (2002) [18], Simatupang et al. (2002) [39], Van Tulder and Mol (2002) } \\
\text { [22], Davila et al. (2003) [24], Skjott-Larsen et al. (2003) [40], Ghiassi and Spera } \\
\text { (2003) [41], Jelassi and Leenen (2003) [42], Karkkainen (2003) [43], } \\
\text { Karkkainenet al. (2003) [44], Kumar and Zahn (2003) [45] }\end{array}$ \\
\hline $\begin{array}{c}\text { BOSC and } \\
\text { organizational }\end{array}$ & $\begin{array}{l}\text { Sonntag (2000) [46], Papazoglouet al. (2000) [47], Dedricket al. (2001) [48], } \\
\text { Jarratt and Fayed (2001) [49], Walters and Buchanan (2001) [50], Carayannis } \\
\text { and Sagi (2001) [51], Childerhouse et al. (2002) [52]. }\end{array}$ \\
\hline Competitiveness & $\begin{array}{l}\text { Prastacoset al. (2002) [53], Alessandri and Bettis (2003) [46], } \\
\text { Holweg and Miemczyk (2003) [54], Holweg and Miemczyk (2003) [55] }\end{array}$ \\
\hline $\begin{array}{l}\text { Customization } \\
\text { and } \\
\text { postponement } \\
\text { strategy }\end{array}$ & $\begin{array}{l}\text { Partanen and Haapasalo (2004) [56], Sonntag (2000) [57], Svensson \& Barfod } \\
\text { (2002) [20], Fredriksson \& Gadde (2005) [58] }\end{array}$ \\
\hline
\end{tabular}

According to Sun et al. (2006) Build-to-Order (BTO) supply chain management system have the capability to quickly build standard or mass-customized products upon receipt of spontaneous orders without forecasts, inventory, or purchasing delays [6]. In this environment products may be shipped directly to individual customers, to stores or dealers, or as a response to assemblers' "pull signals" (assemblers' signals that certain parts are needed right away for assembly).This chain reduces the dependence on forecasts, batches, inventory, or working capital. The basic strategies for implementing Build-to-Order are supply chain simplification, concurrent design of versatile products and flexible processes, the mass customization of variety, and the development of a spontaneous supply chain. Building system to order means there is no finished product inventory in channel to manage. However, the BTO system relies strongly on the tight integration of the upstream supplier of part, the midstream manufacturer and assembly of component, and the downstream distributor of finished goods in the supply chain.

Agarwal et al. (2006) stated that for successful implementation of the BTO phase, it is necessary to consider demand-management technique to manage fluctuation in volume, including marketing incentives, pricing strategy and in- 
creased flexibility with supplier, all of which help balance supply with demand and allow the pipeline to change the right along with the consumer demand [59].

\section{Research Methodology}

For the purpose of this research, we have also studied Dell Inc. background, their business model (direct sales model), customer relationship, build-to-order production, refinement of their model, sale and services. Studies on previous research work on DELL Inc. and its success in computer manufacturing industries directs that applying BOSC strategy on laptop manufacturing will be so much profitable.

The primary aim of the literature search was to help researchers and practitioners develop an effective BOSC and by implementing it improve the supply chain profitability of DELL Inc. To check the feasibility of this proposal we have gone through several stages. All the stages were done with respect to the country Bangladesh and between the potential buyers of laptop computers. Our research objectives are: 1) To provide customer laptop according their preference, 2) To eliminate unnecessary stage from supply chain, 3) To maximize company market share and gaining more profit.

To satisfy the objectives, our research paper is classified into the following sections: 1) Market Analysis, 2) Designing build-to-order supply chain network, 3) Build-to-order management strategy, 4) Profit calculation, 5) Location selection to build assembly plant and warehouse, 6) Result and discussion, 7) Conclusion, and 8) reference.

\section{Market Analysis}

We have performed a market research on the annual market share of personal computer which includes desktop computers, laptop and notebook as well. DELL started their business at 1984. At first stage they grabbed a tiny market share. At the staring ten years that was not an easy time for DELL Inc. To increase their market share they go through a new strategy named Build-To-Order supply chain management and their market share was increasing drastically within decades. According to Zuckerman (1997) Dell has streamlined both procurement and inventory by redesigning its computer so that different models utilize as many of the same components as possible [60]. This reduced the number of inventory parts and the complexity of managing their procurement. Between 1992 and 1997, Dell reduced its 200 plus suppliers by 75 percent. The overall annual market share amongst the leading computer vendors starting the year 1996 to the year 2016 has been adjusted in Tables 2-6 and the data has been collected from the source gartner technology [61].

From the above analysis represented into Tables 2-6 which includes total market share of the major computer manufacturers around the world covering the timeline of 1985-2017. It is clearly visual that total PC market share of Dell Inc. has gone through ups and downs several times in this timeline. But their 
Table 2. Global PC market share by units, percent (2011-2015).

\begin{tabular}{cccccc}
\hline Rank & 2011 & 2012 & 2013 & 2014 & 2015 \\
\hline 1 & HP 16.6 & HP 16.1 & Lenovo 16.9 & Lenovo 18.8 & Lenovo 19.8 \\
2 & Lenovo 12.5 & Lenovo 14.9 & HP 16.2 & HP 17.5 & HP 18.2 \\
3 & Dell 11.7 & Dell 10.7 & Dell 11.6 & Dell 12.8 & Dell 13.6 \\
4 & Acer & Acer 10.2 & Acer 8.0 & Acer 7.9 & Asus 7.3 \\
5 & Asus 5.7 & Asus 6.9 & Asus 6.6 & Asus 7.2 & Apple 7.2 \\
Others & 42.8 & 41.2 & 40.7 & 35.7 & 33.9 \\
\hline
\end{tabular}

Table 3. Global PC market share by units, percent (2006-2010).

\begin{tabular}{cccccc}
\hline Rank & 2006 & 2007 & 2008 & 2009 & 2010 \\
\hline 1 & Dell 15.9 & HP 18.1 & HP 18.2 & HP 19.1 & HP 17.9 \\
2 & HP 15.9 & Dell 14.2 & Dell 14.1 & Acer 12.9 & Acer 13.9 \\
3 & Acer 7.6 & Acer 9.7 & Acer 10.6 & Dell 12.1 & Dell 12.0 \\
4 & Lenovo 7.0 & Lenovo 7.4 & Lenovo 7.5 & Lenovo 8.0 & Lenovo 10.9 \\
5 & Toshiba 3.8 & Toshiba 4.0 & Toshiba 4.6 & Toshiba 5.0 & Asus 5.4 \\
Others & 49.8 & 46.5 & 44.9 & 42.8 & 40.0 \\
\hline
\end{tabular}

Table 4. Global PC market share by units, percent (2001-2005).

\begin{tabular}{cccccc}
\hline Rank & 2001 & 2002 & 2003 & 2004 & 2005 \\
\hline 1 & HP 18.4 & HP 14.2 & Dell 14.9 & Dell 16.4 & Dell 16.8 \\
2 & Dell 13.2 & Dell 13.2 & HP 14.6 & HP 14.6 & HP 14.6 \\
3 & IBM 6.4 & IBM 5.2 & IBM 5.3 & Lenovo 6.8 & Lenovo 6.9 \\
4 & NEC 3.8 & Fujitsu 3.8 & Fujitsu 3.7 & Fujitsu 3.8 & Acer 4.6 \\
5 & Toshiba 2.8 & Toshiba 2.8 & Acer 2.9 & Acer 3.4 & Toshiba 3.3 \\
Others & 55.4 & 60.9 & 58.6 & 55.1 & 53.8 \\
\hline
\end{tabular}

Table 5. Worldwide Market Share in percentage (\%) (based on Unit shipment).

\begin{tabular}{ccccccc}
\hline Manufacturer & 1985 & 1990 & 1995 & 1996 & 1997 & 1998 \\
\hline Compaq & 3 & 4 & 10 & 10.1 & 13.1 & 13.8 \\
IBM & 25 & 13 & 8 & 13.1 & 8.6 & 8.2 \\
Dell & less than 1 & less than 1 & 3 & 8.6 & 5.5 & 7.9 \\
Hewlett-Packard & 2 & 1 & 4 & 4 & 5.3 & 5.8 \\
\hline
\end{tabular}

Table 6. Top 6 vendors by number of units shipped, 2016-2017.

\begin{tabular}{cccccc}
\hline Rank & Brand & $\begin{array}{c}\text { Market Share, } \\
2016\end{array}$ & Manufacturer & Country & $\begin{array}{c}\text { Market Share, } \\
2017\end{array}$ \\
\hline 1 & Lenovo & 20.4 & Acer & Taiwan & 8.0 \\
2 & HP & 19.4 & Apple Inc. & United States & 10.0 \\
3 & Dell & 14.7 & Asus & Taiwan & 10.0 \\
4 & Asus & 7.6 & Dell Inc. & United States & 16.4 \\
5 & Apple & 6.9 & HP & United States & 23.4 \\
6 & Acer & 6.8 & Lenovo & China & 20.1 \\
& & & Others & & 12.1 \\
\hline
\end{tabular}


huge success and the breakthrough to the sales margin is only happened as the BOSC strategy had been applied. During the time period of 1997 to 2006 almost a decade long time Dell held the leading position of the global computer market. After that they lost their achieved top position and reached to the third within a very little glance of time as they have changed their strategy of manufacturing. This happened as they had decided to leave the BOSC strategy to MTO strategy for standardized goods which seems to us a major reason for losing their peak position in the global manufacturing world.

The overall effectiveness of Dell's direct model is indicated by the company's growth in sales and market share. According to Sun et al. (2006) between the year 1990 to 1998, Dell sales have increased from a mere \$389 million in fiscal year 1990 to $\$ 18.2$ billion in fiscal year 1999 which has been represented into Figure 1 [6]. (Ending January 1999, we refer to this as 1998 data in comparative figure to provide comparability with other company's annual data.) Other years are adjusted accordingly [62].

Statistics has been shown in Table 7 from the help of tech-insider [63] where that unit sales of PC to global market although was growing at an enormously rate till the year 2011 but a significant declining rate have been observed after that year and the trend of shrinkage of total sales continuing till now. Based on the statistical analysis we have gone through the decision that applying BOSC strategy with a new vision in laptop manufacturing. As technology is improving day to day so people now want compact devices like laptop, notebook, and mini/microcomputers over personal computers.

\section{Designing Build-to-Order Supply Chain Network}

Supply chain network have become an important topic in this era. Industries, organizations around the world are focusing on supply chain network. The different stages of supply chain play an important role in supply chain cost. For

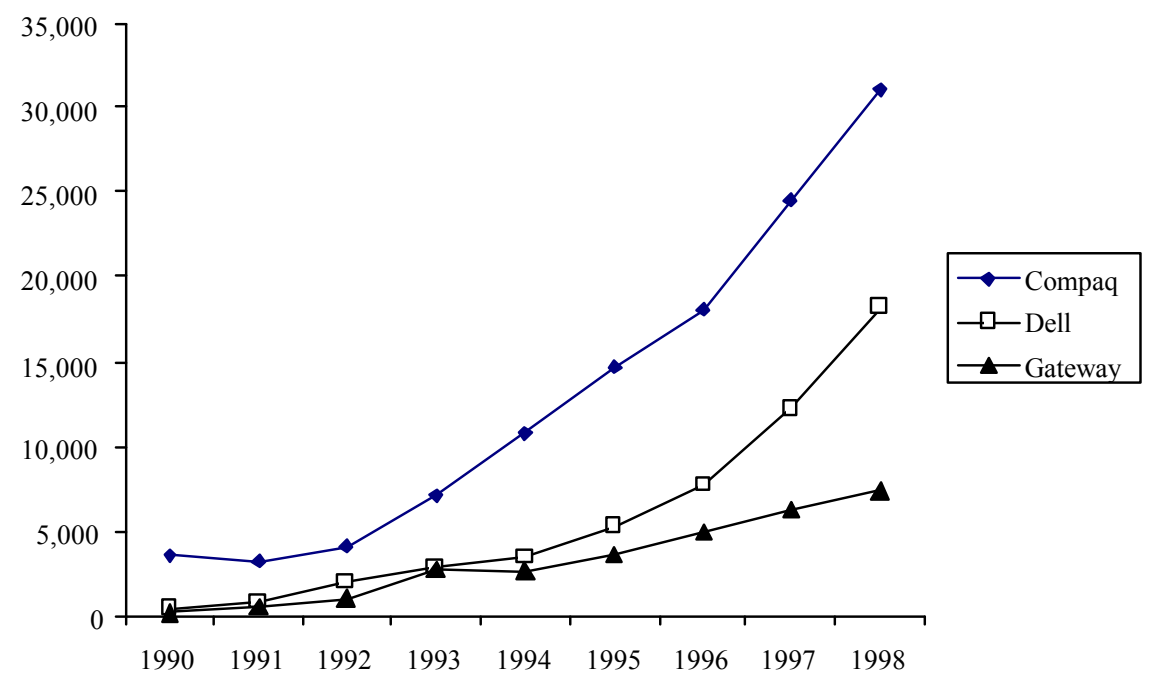

Figure 1. Revenue (in \$ million) from 1990 to 1998 [62]. 
Table 7. Unit sales to global PC market from 1996 to 2005.

\begin{tabular}{cccccc}
\hline Year & Unit $(\mathrm{M})$ & Growth (pct.) & Year & Unit (M) & Growth (pct.) \\
\hline 1997 & 80.6 & 13.7 & 2007 & 271.2 & 13.3 \\
1998 & 92.9 & 15.3 & 2008 & 302.2 & 11.4 \\
1999 & 113.5 & 22.2 & 2009 & 305.9 & 1.2 \\
2000 & 134.7 & 18.7 & 2010 & 351 & 14.7 \\
2001 & 128.1 & -4.9 & 2011 & 352.8 & 0.5 \\
2002 & 132.4 & 3.4 & 2012 & 352.7 & 0.0 \\
2003 & 168.9 & 27.6 & 2013 & 316 & -10.4 \\
2004 & 189.0 & 11.9 & 2014 & 315.9 & -0.2 \\
2005 & 218.5 & 15.6 & 2015 & 287.7 & -8.9 \\
2006 & 239.4 & 9.6 & 2016 & 269.7 & -6.3 \\
\hline
\end{tabular}

that reasons different organization, Industry etc. are trying to apply effective supply chain network to gain more profit. Existing supply chain network of Dell Inc. is shown in Figure 2.

According to sultana et al. (2016), Munna et al. (2015) and Mondal et al. (2017) the more complexity is in supply chain, the more the cost is [3] [4]. We have proposed a new supply chain network for Build-to-order starter in laptop manufacturing in Figure 3 which eliminates the distributor and retailer stages.

\section{Build-To-Order Management Strategy}

To achieve success from a new strategy depends on the effective and proper management in the strategic environment. The information flow plays an important part in the effective management. The more effective information flow on the supply chain, the more effective management becomes. An information flow network diagram is given in Figure 4 which would make more effective the build-to-order supply chain management for laptop production (this model is based on assumption and proposed concept).

Here is a brief description to the proposal and how a customer order will be fulfilled. As given in the network diagram in Figure 4, "Customer will go the showroom, Inform about their laptop specification and then the officer in the showroom will confirm if it is feasible to build their specification. If yes, then officer will receive the order and send it to the assembly plant. If no, then reject the order and inform the customer. If they have any unnecessary circumstances occurs (i.e. sudden decisions can't be made), then the officer in the showroom will send the customer specification to assembly plant or plant in charge directly and after getting valid information he will share it to the customer whether it is feasible or if any further modification need to be made as he instructed from the plant in charge".

\section{Profit Calculation}

Commission in different percentage associates with different stages like custom office, distributor and retailer in supply chain from the source of Bangladesh 


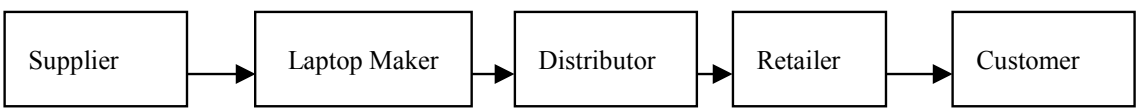

Figure 2. Existing supply chain network.

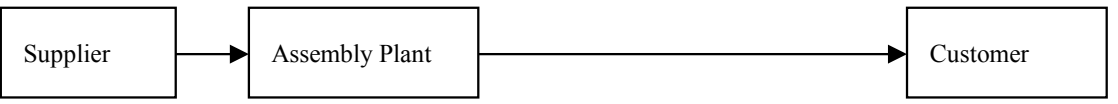

Figure 3. Proposed Build-to-order supply chain network for laptop manufacturing.

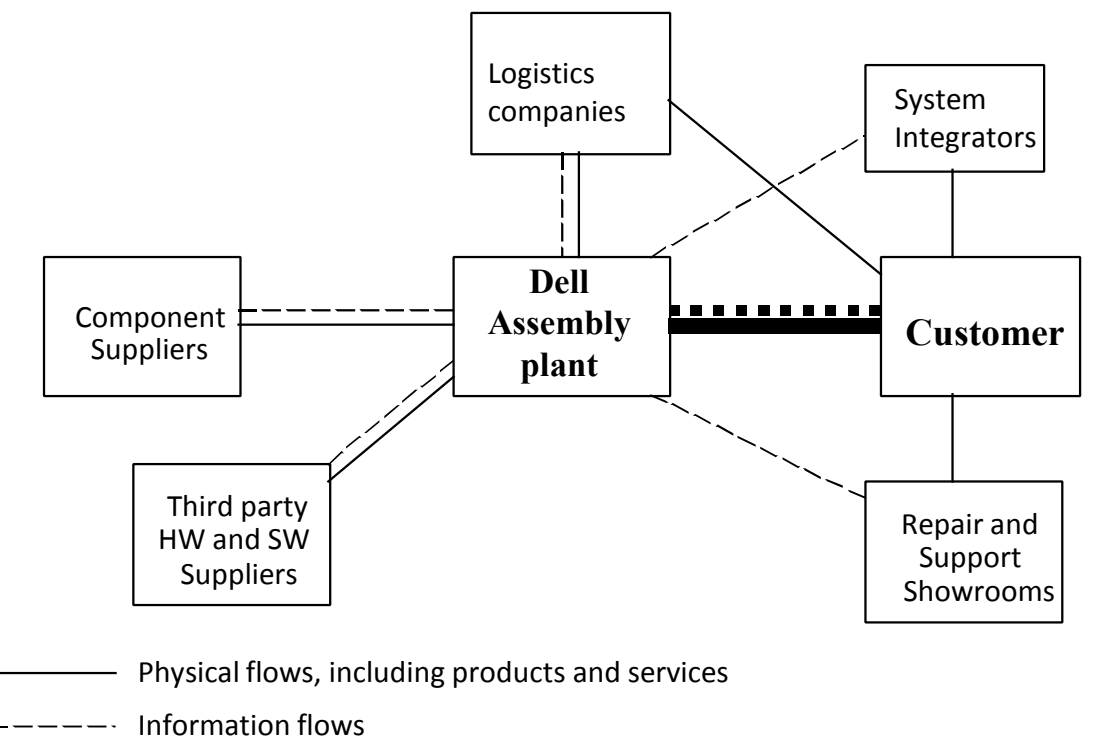

Figure 4. Information flow in the proposed build-to-order supply chain network.

customs trade information [64]. At the existing supply chain network, it can be said that custom office, retailer and distributor are taking a large amount of profit. In our proposed supply chain network, Dell Inc. will also be able to gain that large amount the profit that is gained by custom office, retailer and distributor. A calculation of how much extra profit Dell Inc. will gain after applying our proposed build-to-order supply chain management for laptop manufacturing is given bellow:

According to Table 8,

Average custom office commission (Finished Product) $=(14 \%+25 \%) / 2=$ $19.5 \%$

Average custom office commission (Parts product $)=(8 \%+14 \%) / 2=11 \%$

Distributor commission $=(10 \%+12 \%) / 2=11 \%$

Retailer commission $=(12 \%+14 \%) / 2=13 \%$

Let,

The number of parts that is to be assembled for a customized laptop: $n$

The average cost of the parts $=x_{1}, X_{2}, X_{3}, \ldots X_{n}$

$x=x_{1}+x_{2}+x_{3}+\ldots x_{n}$

Average cost per Laptop (in case of existing environment) $=X$

Company's profit in the existing supply chain environment $=y \%$ 
Table 8. Commission at each supply chain stages (in prospect of Bangladesh).

\begin{tabular}{ccc}
\hline \multirow{2}{*}{ Stages } & \multicolumn{2}{c}{ Commission } \\
\cline { 2 - 3 } & Finished Goods & Part Goods \\
\hline Custom Office & $14 \%-25 \%$ & $8 \%-14 \%$ \\
Distributor & $10 \%-12 \%$ & \\
Retailer & $12 \%-14 \%$ & \\
\hline
\end{tabular}

Then company's profit in case of proposed supply chain environment $=\mathrm{F}(y \%)$ Now, in the existing supply chain environment:

Dell Inc. sells a laptop at price $=x \times y \%+x$

After crossing the custom office the price becomes $=(x \times y \%+x)+(x \times y \%+$ x) $19.5 \%$

That is the price which distributor have to pay to bring a laptop $=\{(x \times y \%+x)+(x \times y \%+x) 19.5 \%\}+\{(x \times y \%+x)+(x \times y \%+x) 19.5 \%\} 11 \%$ That is the price which has to pay retailer to bring a laptop from distributor and finally retailer sells the laptop to customer at the following price

$$
\begin{aligned}
= & {[\{(x \times y \%+x)+(x \times y \%+x) 19.5 \%\}+\{(x \times y \%+x)+(x \times y \%+x) 19.5 \%\}} \\
& 11 \%]+[\{(x \times y \%+x)+(x \times y \%+x) 19.5 \%\}+\{(x \times y \%+x)+(x \times y \%+x) \\
& 19.5 \%\} 11 \%] 13 \% \\
= & 1.5 x \times y \%+149.89 \% x
\end{aligned}
$$

We get a laptop at the price $=(1.5 x \times y \%+149.89 \% x)$

In the proposed supply chain environment:

If Dell Inc. sells their laptop at the above price in our proposed supply chain environment, then their new percentage profit will be $\mathrm{F}(\mathrm{y} \%)$

The value of the function is determined below:

Average cost per laptop in the proposed supply chain environment

$$
\begin{aligned}
& =\left(x_{1} \times 11 \%+x_{2} \times 11 \%+x_{3} \times 11 \%+\ldots x_{n} \times 11 \%\right)+\left(x_{1}+x_{2}+x_{3}+\ldots x_{n}\right) \\
& =11 \% \times\left(x_{1}+x_{2}+x_{3}+\ldots x_{n}\right)+\left(x_{1}+x_{2}+x_{3}+\ldots x_{n}\right) \\
& =111 \% \times\left(x_{1}+x_{2}+x_{3}+\ldots x_{n}\right) \\
& =x \times 111 \%
\end{aligned}
$$

Profit gained in build to order Environment:

$=(1.5 x \times y \%+149.89 \% x)-(111 \% x)$

$$
=1.5 x \times y \%+38.89 \% x
$$

Percentage profit gained in build-to-order environment

$=(1.5 x y \%+38.89 \% x) / x$

$=1.5 y \%+38.89 \%$

So, $\mathrm{F}(y \%)=1.5 y \%+38.89 \%$

Extra profit will gain $=\mathrm{F}(y \%)-y \%$

$$
\begin{aligned}
& =(1.5 y \%+38.89 \%)-y \% \\
& =0.5 y \%+38.89 \%
\end{aligned}
$$

\section{Location Selection to Build Assembly Centre and Warehouse}

As most important objectives in this research is to provide laptops to the cus- 
tomers by their preferred configuration not by offering a standard mass production quality laptop. So a very important question is been rising now. That is where the assembly plant should be located and how the warehousing be done, which drives to the pace of building ware house and assembly house. To fulfill this objective, depending upon several criteria and location selection method we have offered a location for warehousing the supplies and also construction of plant. As both procedures requires a very large space and also environmental friendly area for an international computer manufacturing corporation the place is primarily choose is at Kashimpur, Gazipur Sadar, Gazipur. Very close to the industrial area where transport facilities will be quiet good. DELL Inc. has to establish an assembly house and showroom in Bangladesh. Depending upon various important criteria, we have identified required quantity, place of showroom and assembly house respectively.

The research work is done basically from the works available on Dell supply chain network and their business model. Using the data's that are availed from previous research work a business proposal has just been introduced through this paper. At the very beginning stage of starting the business Dell Inc. must establish an assembly plant where they will complete the necessary works related to manufacturing of customized laptop. For primary selection a plant location is been introduced in this paper located at Kashimpur, Gazipur Sadar, Gazipur. The location will cover a huge space which can be easily occupied for the construction of warehouse and the assembly plant. Dell Inc. must also establish their brand showroom including service centers of their own to reach maximum customer satisfaction.

\section{Results and Discussion}

Data's has been gathered from several sources. Research paper that containing the information of how Dell Inc. success through using the build-to-order supply chain management strategy and pioneering this method how they incorporated a great market share has inspired to rethink about the strategy and to re-implement the strategy in laptop manufacturing. Research paper published on international journals i.e. Journal of Operations Management, Journal of Operations Research and Information Systems, Computer \& Industrial Engineering and the International Journal of Operations and Production Management, International Journal of Production Economics which are published by Elsevier, Emerald, Tailor, Francis and Research Gate in the areas of supply chain specially on the build-to-order model was so inspiring that by using this strategy again Dell Inc. may lead the market once again.

It has also been represented that the market for personal computers are declining. New technologies like laptop, smartphones and virtual realities have now become more demandable than conventional PCs. As laptop market is substantially rising it would be a wiser decision to make a new strategy and embrace the market with success again. Why Dell? As Dell Inc. has previously applied this 
strategy and captured a huge market among the PC maker industries all over world so it is easy to say that they have a very efficient and effective management team. And as also a leading tech company one of the biggest manufacturer of computers and laptops this would not be very hard to invest for the implementation of the new strategy in laptop manufacturing. For the proposal and as feasibility analysis a profit calculation and an assembly plant have been introduced in this paper which is done as prospects to Bangladesh. The taxes and excise duties for trading of electronic sub-parts, parts, partial goods, raw item and finished goods are taken directly from Customs Office Bangladesh also shown in Table 8. How much retailer and distributer profit is annexed from RIANS, SMART Technologies and GLOBAL Brand Pvt. Limited respectively? As these three companies are the largest authorized distributor DELL laptops sold in Bangladesh. Laptop sales forecasting policy is hired from GLOBAL which helps to build the profit calculation task. To propose the location of assembly plant an example is taken (Walton High Tech Facility) which is one of the biggest high tech. industry in Bangladesh.

The profit calculation also suggests a great profit margin increment in sales of laptops. If for manufacturing and solely distribution of laptops Dell Inc. makes a profit of $y \%$ by applying the BOSC strategy the company will be easily able to gain an extra $0.5 \times y \%+38.89 \%$. Though this margin does not offer the actual profit amount. There are several sectors which would require a massive investment to implement such a new strategy and also for marketing of this strategy. But it can be still said boldly that this would certainly provide a huge market share for Dell Inc. in laptop manufacturing and selling all over the world.

\section{Conclusion}

SCM is important topic in this era. All industry and organization want to go through effective SCM process. To sustain in the competitive business world, it is necessary to innovate tactics in SCM. Mainly the project is done on an innovative tactic in supply chain management. In this project, we have tried to give the complete information to start a new business with BOSC tactics in Bangladesh. Different analysis and estimation have been done in this project, such as market analysis, profit estimation. From the above analysis, it can be said that if DELL Inc. starts their business with Build-to-Order supply chain tactic, they will be able to increase more market share and gain more profit.

\section{References}

[1] Beamon, B.M. (1998) Supply Chain Design and Analysis: Models and Methods. International Journal of Production Economics, 55, 281-294. https://doi.org/10.1016/S0925-5273(98)00079-6

[2] Munna, M.M., Rahman, M.H. and Roney, M.F.S. (2015) Comparative Analysis for Multicriteria Inventory Classification of Unilever Brothers Ltd. Using AHP and Fuzzy AHP Models. International Journal of Automotive Technology, 2, 377-382.

[3] Sultana, M.N., Rahman, M.H. and Al Mamun, A. (2016) Multi Criteria Decision 
Making Tools for Supplier Evaluation and Selection: A Review. European Journal of Advances in Engineering and Technology, 3, 56-65.

[4] Mondal, P.K., Rahman, M.H., SanoarHosin, M. and Sarkar, P. (2017) An AHP Based Approach to Identify and Eliminate Most Severe Risks of the Internal Supply Chain of Ready Made Garments (RMG) Industries: A Case Study. International Journal of Economics, Finance and Management Sciences, 5, 168-172. https://doi.org/10.11648/j.ijefm.20170503.15

[5] Gunasekaran, A. and Ngai, E.W. (2005) Build-to-Order Supply Chain Management: A Literature Review and Framework for Development. Journal of Operations Management, 23, 423-451. https://doi.org/10.1016/j.jom.2004.10.005

[6] Sun, J., Hui, X. and Li, M. (2006) An Internet-Based Multi-Agent Framework for Build-to-Order Supply Chain Management. The Sixth World Congress on Intelligent Control and Automation, WCICA, 2, 7029-7033.

[7] Brown, E. (1999) Selling to Businesses: Dell Computer. Fortune, 43, 74.

[8] Hausman, W.H. (2004) Supply Chain Performance Metrics. The Practice of Supply Chain Management. Where Theory and Application Converge, Springer, Boston, MA, 61-73. https://doi.org/10.1007/0-387-27275-5_4

[9] Noorul Haq, A. and Kannan, G. (2006) Design of an Integrated Supplier Selection and Multi-Echelon Distribution Inventory Model in a Built-to-Order Supply Chain Environment. International Journal of Production Research, 44, 1963-1985. https://doi.org/10.1080/00207540500381427

[10] Gosling, J. and Naim, M.M. (2009) Engineer-to-Order Supply Chain Management: A Literature Review and Research Agenda. International Journal of Production Economics, 122, 741-754. https://doi.org/10.1016/j.ijpe.2009.07.002

[11] Christensen, W.J., Germain, R. and Birou, L. (2005) Build-to-Order and Just-in-Time as Predictors of Applied Supply Chain Knowledge and Market Performance. Journal of Operations Management, 23, 470-481. https://doi.org/10.1016/j.jom.2004.10.007

[12] Ho, L.T. and Lin, G.C.I. (2004) Critical Success Factor Framework for the Implementation of Integrated-Enterprise Systems in the Manufacturing Environment. International Journal of Production Research, 42, 3731-3742. https://doi.org/10.1080/00207540410001721781

[13] Prasad, S., Tata, J. and Madan, M. (2005) Build-to-Order Supply Chains in Developed and Developing Countries. Journal of Operations Management, 23, 551-568. https://doi.org/10.1016/j.jom.2004.10.011

[14] Holweg, M. and Pil, F.K. (2001) Successful Build-to-Order Strategies Start with the Customer. MIT Sloan Management Review, 43, 74-83.

[15] Cravens, D.W., Piercy, N.F. and Prentice, A. (2000) Developing Market Driven Product Strategies. Journal of Product and Brand Management, 9, 369-388. https://doi.org/10.1108/10610420010356975

[16] Vrijhoef, R. and Koskela, L. (2000) The Four Roles of Supply Chain Management in Construction. European Journal of Purchasing and Supply Management, 6, 169-178. https://doi.org/10.1016/S0969-7012(00)00013-7

[17] Forza, C. and Salvador, F. (2002) Managing for Variety in the Order Acquisition and Fulfillment Process: The Contribution of Product Configuration Systems. International Journal of Production Economics, 76, 87-98. https://doi.org/10.1016/S0925-5273(01)00157-8

[18] Muffato, M. and Payaro, A. (2004) Implementation of e-Procurement and 
e-Fulfillment Processes: A Comparison of Cases in the Motorcycle Industry. International Journal of Production Economics, 89, 339-351. https://doi.org/10.1016/S0925-5273(02)00301-8

[19] Power, D.J. and Sohal, A.S. (2002) Implementation and Usage of Electronic Commerce in Managing the Supply Chain. Benchmarking. An International Journal, 9 , 190-208. https://doi.org/10.1108/14635770210421854

[20] Svensson, C. and Barford, A. (2002) Limits and Opportunities in Mass Customization for Build-to-Order SMEs. Computers in Industry, 49, 7789. https://doi.org/10.1016/S0166-3615(02)00060-X

[21] Thonemann, U.W. and Bradley, J.R. (2002) The Effect of Product Variety on Supply-Chain Performance. European Journal of Operational Research, 143, 548-569. https://doi.org/10.1016/S0377-2217(01)00343-5

[22] Van Tulder, R. and Mol, M. (2002) Reverse Auctions or Auctions Reversed: First Experiments by Philips. European Management Journal, 20, 447-456. https://doi.org/10.1016/S0263-2373(02)00099-3

[23] Chopra, S. (2003) Designing the Distribution Network in a Supply Chain. Transportation Research Part E, 39, 123-140. https://doi.org/10.1016/S1366-5545(02)00044-3

[24] Davila, A., Gupta, M. and Palmer, R. (2003) Moving Procurement Systems to the Internet: The Adoption and Use of e-Procurement Technology Models. European Management Journal, 21, 11-23. https://doi.org/10.1016/S0263-2373(02)00155-X

[25] Erhun, F. and Tayur, S. (2003) Enterprise-Wide Optimization of Total Landed Cost at a Grocery Retailer. Operations Research, 51, 343-353. https://doi.org/10.1287/opre.51.3.343.14953

[26] Banker, R.D. and Khosla, I.S. (1983) Economics of Operations Management: A Research Perspective. Journal of Operations Management, 12, 423-435. https://doi.org/10.1016/0272-6963(95)00022-K

[27] Glasserman, P. and Wang, Y. (1998) Leadtime-Inventory Trade-Offs in Assemble-to-Order Systems. Operations Research, 46, 858-871. https://doi.org/10.1287/opre.46.6.858

[28] Krause, D.R., Handfield, R.B. and Scannell, T.V. (1998) An Empirical Investigation of Supplier Development: Reactive and Strategic Processes. Journal of Operations Management, 17, 39-58. https://doi.org/10.1016/S0272-6963(98)00030-8

[29] Chen, F., Drezner, Z., Ryan, J.K. and Simchi-Levi, D. (2000) Quantifying the Bullwhip Effect in a Simple Supply Chain: The Impact of Forecasting, Lead Times, and Information. Management Science, 46, 436-443. https://doi.org/10.1287/mnsc.46.3.436.12069

[30] Chen, R.-S., Lu, K.-Y., Yu, S.-C., Tzeng, H.-W. and Chang, C.C. (2003) A Case Study in the Design of BTO/CTO Shop Floor Control System. Information and Management, 41, 25-37. https://doi.org/10.1016/S0378-7206(03)00003-X

[31] Griffiths, J. and Margetts, D. (2000) Variation in Production Schedules-Implications for Both the Company and Its Suppliers. Journal of Materials Processing Technology, 103, 155-159. https://doi.org/10.1016/S0924-0136(00)00408-8

[32] Kolisch, R. (2000) Integration of Assembly and Fabrication for Maketo-Order Production. International Journal of Production Economics, 68, 287-306. https://doi.org/10.1016/S0925-5273(99)00011-0

[33] Song, J.-S. and Yao, D.D. (2002) Performance Analysis and Optimization of Assem- 
ble-to-Order Systems with Random Lead Times. Operations Research, 50, 889-903. https://doi.org/10.1287/opre.50.5.889.372

[34] Geunes, J. (2003) Solving Large-Scale Requirements Planning Problems with Component Substitution Options. Computers and Industrial Engineering, 44, 475-491. https://doi.org/10.1016/S0360-8352(02)00232-2

[35] Wagner, T., Guralnik, V. and Phelps, J. (2003) TAEMS Agents: Enabling Dynamic Distributed Supply Chain Management. Electronic Commerce Research and Applications, 2, 114-132. https://doi.org/10.1016/S1567-4223(03)00014-0

[36] Biswas, S. and Narahari, Y. (2004) Object Oriented Modeling and Decision Support for Supply Chains. European Journal of Operational Research, 153, 704-726. https://doi.org/10.1016/S0377-2217(02)00806-8

[37] Kraemer, K.L. and Dedrick, J. (2002) Strategic Use of the Internet and Ecommerce: Cisco Systems. Journal of Strategic Information Systems, 11, 5-29. https://doi.org/10.1016/S0963-8687(01)00056-7

[38] Morris, L.J. and Morris, J.S. (2002) The Changing Role of Middlemen in the Distribution of Personal Computers. Journal of Retailing and Consumer Services, 9, 97-105. https://doi.org/10.1016/S0969-6989(01)00027-3

[39] Simatupang, T.M., Wright, A.C. and Sridharan, R. (2002) The Knowledge of Coordination for Supply Chain Integration. Business Process Management Journal, 8, 289-308. https://doi.org/10.1108/14637150210428989

[40] Skjott-Larsen, T., Kotzab, H. and Grieger, M. (2003) Electronic Marketplaces and Supply Chain Relationships. Industrial Marketing Management, 32, 199-210. https://doi.org/10.1016/S0019-8501(02)00263-8

[41] Ghiassi, M. and Spera, C. (2003) Defining the Internet-Based Supply Chain System for Mass Customized Markets. Computers and Industrial Engineering, 45, 17-41. https://doi.org/10.1016/S0360-8352(03)00017-2

[42] Jelassi, T. and Leenen, S. (2003) An e-Commerce Sales Model for Manufacturing Companies: A Conceptual Framework and a European Example. European Management Journal, 21, 38-47. https://doi.org/10.1016/S0263-2373(02)00151-2

[43] Karkkainen, M. (2003) Increasing Efficiency in the Supply Chain for Short Life Goods Using RFID Tagging. International Journal of Retail and Distribution Management, 31, 529-536. https://doi.org/10.1108/09590550310497058

[44] Karkkainen, M., Holmstrom, J., Framling, K. and Artto, K. (2003) Intelligent Products-A Step towards a More Effective Project Delivery Chain. Computers in Industry, 50, 141-151. https://doi.org/10.1016/S0166-3615(02)00116-1

[45] Kumar, S. and Zahn, C. (2003) Mobile Communications: Evolution and Impact on Business Operations. Technovation, 23, 515-520. https://doi.org/10.1016/S0166-4972(02)00120-7

[46] Sonntag, V. (2000) Sustainability-In Light of Competitiveness. Ecological Economics, 34, 101-113. https://doi.org/10.1016/S0921-8009(00)00141-5

[47] Papazoglou, M.P., Ribbers, P. and Tsalgatidou, A. (2000) Integrated Value Chains and Their Implications from a Business and Technology Standpoint. Decision Support Systems, 29, 323-342. https://doi.org/10.1016/S0167-9236(00)00081-6

[48] Dedrick, J., Kraemer, K.L., Palacios, J.J. and Tigre, P.B. (2001) Economic Liberalization and the Computer Industry: Comparing Outcomes in Brazil and Mexico. World Development, 29, 1199-1214. https://doi.org/10.1016/S0305-750X(01)00038-9

[49] Jarratt, D. and Fayed, R. (2001) The Impact of Market and Organizational Chal- 
lenges on Marketing Strategy Decision-Making: A Qualitative Investigation of the Business-to-Business Sector. Journal of Business Research, 51, 61-72. https://doi.org/10.1016/S0148-2963(99)00040-5

[50] Walters, D. and Buchanan, J. (2001) The New Economy, New Opportunities and New Structures. Management Decision, 39, 818-833. https://doi.org/10.1108/EUM0000000006524

[51] Carayannis, E. and Sagi, J. (2001) New vs. Old Economy: Insights on Competitiveness in the Global IT Industry. Technovation, 21, 501-514.

[52] Childerhouse, P., Aitken, J. and Towill, D.R. (2002) Analysis and Design of Focused Demand Chains. Journal of Operations Management, 20, 675-689. https://doi.org/10.1016/S0272-6963(02)00034-7

[53] Prastacos, G., Soderquist, K., Spanos, Y. and van Wassenhove, L. (2002) An Integrated Framework for Managing Change in the New Competitive Landscape. European Management Journal, 20, 55-71. https://doi.org/10.1016/S0263-2373(01)00114-1

[54] Alessandri, T.M. and Bettis, R.A. (2003) Surviving the Bulls and the Bears: Robust Strategies and Shareholder Wealth. Long Range Planning, 36, 13-35. https://doi.org/10.1016/S0024-6301(02)00207-8

[55] Holweg, M. and Miemczyk, J. (2002) Logistics in the "3-Day Car" Age: Assessing the Responsiveness of Vehicle Distribution Logistics in the UK. International Journal of Physical Distribution and Logistics Management, 32, 829-850. https://doi.org/10.1108/09600030210455438

[56] Holweg, M. and Miemczyk, J. (2003) Delivering the "3-Day Car"-The Strategic Implications for Automotive Logistics Operations. Journal of Purchasing and Supply Management, 9, 63-71. https://doi.org/10.1016/S1478-4092(03)00003-7

[57] Partanen, J. and Haapasalo, H. (2004) Fast Production for Order Fulfillment: Implementing Mass Customization in Electronics Industry. International Journal of Production Economics, 90, 213-222. https://doi.org/10.1016/S0925-5273(03)00214-7

[58] Fredriksson, P. and Gadde, L.E. (2005) Flexibility and Rigidity in Customization and Build-to-Order Production. Industrial Marketing Management, 34, 695-705. https://doi.org/10.1016/j.indmarman.2005.05.010

[59] Agarwal, A., Shankar, R. and Tiwari, M.K. (2006) Modeling the Metrics of Lean, Agile and Leagile Supply Chain: An ANP-Based Approach. European Journal of Operational Research, 173, 211-225. https://doi.org/10.1016/j.ejor.2004.12.005

[60] Zuckerman, L.K. (1997) Do Computers Lift Productivity? It's Unclear, But Business Is Sold. New York Times, 2.

[61] https://www.gartner.com/technology/home.jsp

[62] Kraemer, K.L., Dedrick, J. and Yamashiro, S. (2000) Refining and Extending the Business Model with Information Technology: Dell Computer Corporation. The Information Society, 16, 5-21. https://doi.org/10.1080/019722400128293

[63] http://tech-insider.org/

[64] http://www.bangladeshcustoms.gov.bd/trade_info/ 